\title{
Detection of Antibiotic Resistant Staphylococcus sp. as a cause of Subclinical Mastitis in Bogor
}

\author{
Feni Rahmawati \\ Student of Faculty of Veterinary \\ Medicine \\ IPB University \\ Bogor, Indonesia \\ feni_rahmawati@apps.ipb.ac.id
}

\author{
Mirnawati B. Sudarwanto \\ Department of Animal Disease and \\ Veterinary Public Health \\ $I P B$ University \\ Bogor, Indonesia
}

\author{
Hadri Latif \\ Department of Animal Disease and \\ Veterinary Public Health \\ $I P B$ University \\ Bogor, Indonesia \\ hadrilatif@gmail.com \\ Herwin Pisestyani \\ Department of Animal Disease and \\ Veterinary Public Health \\ IPB University \\ Bogor, Indonesia
}

\author{
Denny Widaya Lukman \\ Department of Animal Disease and \\ Veterinary Public Health \\ IPB University \\ Bogor, Indonesia
}

\begin{abstract}
Subclinical mastitis is a common and economically significant disease affecting dairy cattle. Staphylococcus sp. found as one of the most frequently major causative agents. The resistance of Staphylococcus sp. against antibiotics on subclinical mastitis cases has not been reported quite frequently. The aim of this study was to determine the antibiotic resistant of Staphylococcus sp. as a cause of subclinical mastitis in Bogor. Milk samples from 188 quarters of cows in Dairy Farms in Bogor, ie. Kelompok Usaha Peternakan (KUNAK) in Cibungbulang, Tapos, Tajur Halang, and Kebon Pedes, were identified by using IPB-1 followed by bacteriological examination. The resistance test was done by using disc diffusion Kirby-Bauer method. The results were taken by measuring inhibition zone diameter and interpreted by referring to Clinical and Laboratory Standards Institute (CLSI 2017). The results from resistance test in 3 isolates of Staphylococcus aureus (S. aureus) and 22 isolates of coagulase-negative Staphylococcus (CNS) showed the high resistance against $\beta$-lactamase antibiotic (penicillin $G$ and ampicillin). Resistance against erythromycin, streptomycin, tetracycline, and ciprofloxacin was shown in CNS but $S$. aureus was still susceptible against these antibiotics. The resistance test results showed that 3 of 22 CNS isolates have multidrug-resistant properties. $S$. aureus and CNS were susceptible against doxycycline and gentamicin so that those antibiotics can be recommendations for subclinical mastitis therapy in Bogor.
\end{abstract}

Keywords-antibiotic resistance, Staphylococcus sp., subclinical mastitis

\section{INTRODUCTION}

Milk is a food commodity of animal origin that contains complete nutrition and in balanced proportions, so its supply as a daily necessity is important to support growth and health of the body [1]. National milk consumption is only around 11.8 liters/capita/year, but the low milk consumption rate cannot be fulfilled through national milk production. The availability of domestic cow's milk is mostly supplied by imported milk (79.93\%), while local cow's milk only contributes $20.07 \%$ [2]. Various polemics underlie the low availability of cow's milk in Indonesia, one of which is inflammation of the internal udder tissue called mastitis [3].

Mastitis is one of the challenges for dairy farmers in Indonesia because it can cause a decrease in milk production [4]. Mastitis generally consists of clinical mastitis and subclinical mastitis [3]. Clinical mastitis is characterized by inflammation of the udder and pus present in milk. Subclinical mastitis shows a good udder condition, not swollen, not sick, and not hot, but there are certain abnormalities in milk so that the incidence of subclinical mastitis is often not realized by farmers [5]. The most important microorganism that causes mastitis is Staphylococcus sp., with Staphylococcus aureus (S. aureus) as the main cause of clinical and subclinical mastitis [6], [7]. Coagulase-negative Staphylococcus (CNS) in recent years has also emerged as a relevant pathogen [8], [9].

Antibiotic therapy is generally implemented for the control and treatment of subclinical mastitis [10]. Treatment failure in subclinical mastitis that caused by Staphylococcus sp. can be found and antibiotic resistance is considered to be one of the causes of low cure rates [11]. Unauthorized use of antibiotics is considered as an important factor that drives antibiotic resistance. As in [12] stated that efforts to reduce the impact of antibiotic resistance and maintain the efficacy of drug use is to strengthen scientific evidence through research and supervision. Based on these conditions, research on the level of bacterial resistance, especially $S$. aureus and CNS needs to be done so that information on bacterial resistance is obtained as well as providing recommendations for antibiotic options that can be used for the treatment of subclinical mastitis.

\section{MATERIALS AND METHODS}

\section{A. Time and Place of Research}

This research was conducted in April to September 2017. Sampling was conducted in four cities/districts in Bogor, namely the Kelompok Usaha Peternakan (KUNAK) in Cibungbulang, Kebon Pedes, Tajur Halang, and Tapos. Bacterial resistance testing was carried out at the Veterinary 
Public Health Laboratory, Department of Animal Disease and Veterinary Public Health.

\section{B. Materials and Tools}

Materials used in this study were samples of quartered milk from dairy cows in the Bogor region, IPB-1 mastitis reagents, violet crystals, lugol, $3 \% \mathrm{H}_{2} \mathrm{O}_{2}$ safranin, sterile toothpicks, oxidase reagents, glucose solutions, immersion oil, 0.5 McFarland solution, cotton swabs, mannitol salt agar/ MSA (Oxoid® CM0085), blood agar, CASO agar (Oxoid® CM0129), sterile distilled water, 70\% alcohol, water, tissue, $10 \%$ Giemsa dye, ethanol, $0.9 \%$ physiological $\mathrm{NaCl}$, rabbit plasma, Müeller Hinton agar/MHA (Oxoid®) CM0337), brain heart infusion/BHI (Oxoid® CM1135), antibiotic discs (penicillin $\mathrm{G}$, ampicillin, tetracycline, doxycycline, erythromycin, ciprofloxacin, gentamicin, and streptomycin).

The tools used in this study were personal protective equipment (lab coats, masks, gloves), paddle, icepacks, coolboxes, petri dishes (diameter $10 \mathrm{~cm}$ ), test tubes (volume $15 \mathrm{ml}$ ), test tube racks, micropipettes, tweezers, inoculating loop/ose, Bunsen burners, Eppendorf tubes, tube shakers, microscopes, water baths, autoclaves, sterile cabinets, refrigerators, $37{ }^{\circ} \mathrm{C}$ incubators, rulers, markers, and heatresistant sterile plastics.

\section{Methods}

\section{1) Sample}

Sampling was carried out in several areas in Bogor, namely the Kelompok Usaha Peternakan (KUNAK) in Cibungbulang, Kebon Pedes, Tajur Halang, and Tapos. A total of 2-3 clinically healthy dairy cows which are in the normal lactation period and there are no physical changes in the udder and milk were chosen from each cage. Each region was selected 4-7 cow dairy cages. The normal lactation period of dairy cows was chosen as a prevention of the occurrence of false positive test results for subclinical mastitis test which can be caused by the normal physiological conditions of livestock, i.e at the beginning and end of lactation [13]. Milk samples as much as 10-15 $\mathrm{mL}$ were collected from 4 quarters. Each sample was then labeled based on the order of sampling and the location of the quarter. The number of samples obtained was 188 quarters.

\section{2) Identification of Subclinical Mastitis Case}

Subclinical mastitis test was performed using IPB-1 reagents. A total of $2 \mathrm{~mL}$ of each sample was dropped by IPB-1 mastitis reagents with a ratio of $1: 1$. Milk samples and reagents were homogenized by shaking the paddle horizontally for 15-30 seconds. The IPB-1 mastitis test was cheap but proved to be sensitive and specific [14]. The reaction gives rise to a thick mass like gelatin. Based on these indicators mastitis scores were determined with,-+1 , $+2,+3$ and +4 . The thicker the mass formed shows the higher reaction, meaning that the number of somatic cells is increasing [15]. Samples that were tested further in this study were those that showed a score of +3 or +4 in testing with IPB-1 reagents. Based on these results, a total of 127 quarters were obtained and were used in the study. The samples that were tested from each region were then stored in a coolbox at $4{ }^{\circ} \mathrm{C}$, then taken to the laboratory.
Inspection of samples in the laboratory does not exceed 72 hours after sampling [16].

\section{3) Isolate Preparation}

Samples that were positive for the IPB-1 test were then tested further. Milk samples were cultured on blood agar and incubated for $20-24$ hours at $37{ }^{\circ} \mathrm{C}$. The colonies formed were observed morphologically and the ability to dissolve blood. Bacterial purification was carried out on CASO media.

Bacterial isolate suspected of Staphylococcus sp. planted in MSA, then catalase, oxidase, and coagulase tests were carried out to further identify bacterial colonies. MSA media is a selective medium for the growth of $S$. aureus which can differentiate from other Staphylococcus species.

\section{4) Culture Preparation}

Colonies of $S$. aureus and CNS bacteria that were successfully identified were inoculated to CASO agar media and incubated at $37{ }^{\circ} \mathrm{C}$ for 24 hours. The isolates were then bred in a brain heart infusion broth for 30-60 minutes at $37{ }^{\circ} \mathrm{C}$. Bacteria that grow then made into suspension in physiological $\mathrm{NaCl} 5 \mathrm{~mL}$. The solution was homogenized by shaking the tube for 2 minutes to form a suspension. The turbidity of the solution obtained was equated to the turbidity of $0.5 \mathrm{McF}$ arland or equivalent to $0.5 \times 10^{8} \mathrm{cfu} / \mathrm{mL}$. The yield was taken as much as $0.1 \mathrm{~mL}$ with a pipette and spread on the MHA.

\section{5) Testing for Bacterial Resistance to Antibiotic}

The bacterial suspension was spread onto the surface of the MHA media with a sterile cotton swab. Antibiotic resistance test was carried out by the disc diffusion method according to Kirby-Bauer, for several types of antibiotics such as penicillin G, tetracycline, doxycycline, gentamicin, streptomycin, ciprofloxacin, ampicillin, and erythromycin. Each petri dish was given 8 antibiotic discs, then incubated at $37{ }^{\circ} \mathrm{C}$ for 24 hours. After incubating for 24 hours, readings were then carried out. The reading was done by measuring the diameter of the inhibition zone in the form of a clear zone that forms around the disk paper. Sensitive $(\mathrm{S})$, intermediate $(\mathrm{I})$, and resistance $(\mathrm{R})$ determinations are determined through inhibition zone sizes that are formed based on Clinical and Laboratory Standards Institute recommendations.

\section{6) Data analysis}

Results obtained were analyzed descriptively in the form of tables and figures using Microsoft Excel 2013.

\section{RESULTS}

\section{A. Occurrences and Agents of Subclinical Mastitis Causes}

188 quarters cow's milk samples from 22 cages in four farms in the Bogor region (Kempok Usaha Peternakan/ KUNAK in Cibungbulang, Tajurhalang, Tapos, and Kebon Pedes) were examined using IPB-1 reagents to detect subclinical mastitis. Milk samples from 127 quarters $(67.6 \%)$ of the results of the subclinical mastitis test (IPB-1 Test) showed positive scores of three $(+3)$ and positive four (+4) subclinical mastitis. The highest quarters infected with 
subclinical mastitis was obtained from Tapos. The number of quarters identified by subclinical mastitis from each farm is presented in Table 1.

TABLE I. Distribution Of THE NUMBER OF POSITIVE UDDER QUARTER OF SUBCLINICAL MASTITIS FROM FOUR ANIMAL HUSBANDRY

\begin{tabular}{|l|c|c|}
\hline \multicolumn{1}{|c|}{ Locations } & $\begin{array}{c}\text { LocATIONS } \\
\text { Number of } \\
\text { quarter }(\mathbf{n})\end{array}$ & Number of positive \\
\hline Kebon Pedes & 60 & $32(17.0 \%)$ \\
\hline Kunak & 48 & $32(17.0 \%)$ \\
\hline Tapos & 40 & $34(18.1 \%)$ \\
\hline Tajur Halang & 40 & $29(15.4 \%)$ \\
\hline Total & 188 & $127(67.6 \%)$ \\
\hline
\end{tabular}

The results of isolation observations on selective media found that from quarter milk samples that showed positive results of subclinical mastitis obtained 25 Staphylococcus isolates consisting of $3(12 \%)$ S. aureus isolates and 22 (88\%) CNS isolates (Table 2).

TABLE II. RESULTS OF THE ISOLATION OF STAPHYLOCOCCUS SP. CAUSES OF SUBCLINICAL MASTITIS

\begin{tabular}{|l|c|c|}
\hline \multicolumn{1}{|c|}{ Type of bacteria } & $\begin{array}{c}\text { Amount } \\
\text { (isolate) }\end{array}$ & $\begin{array}{c}\text { Percentage } \\
(\%)\end{array}$ \\
\hline Staphylococcus aureus & 3 & 12 \\
\hline Coagulase negative Staphylococcus & 22 & 88 \\
\hline
\end{tabular}

\section{B. Antibiotic Resistance}

Observation of $S$. aureus and CNS isolates resistance to antibiotics was done by calculating the inhibitory zone in accordance with the determination of the minimum inhibitory zone. The size of the inhibitory zone determines the bacterial properties of antibiotics based on the standards of each antibiotic. The results of antibiotic resistance tests on $S$. aureus and CNS bacteria can be seen in Table 3 .

TABLE III. RESUlts OF ANTIBIOTIC RESISTANCE TESTS ON STAPHYLOCOCCUS AUREUS (S.AUREUS) AND STAPHYLOCOCUS NEGATIVE COAGULASE (CNS) BACTERIA

\begin{tabular}{|l|c|c|c|c|c|c|}
\hline \multirow{2}{*}{ Antibiotics } & \multicolumn{3}{|c|}{ S. aureus } & \multicolumn{3}{c|}{ CNS } \\
\cline { 2 - 7 } & \multicolumn{3}{|c|}{$\begin{array}{c}\text { Amount (isolate)/ } \\
\text { Percentage (\%) }\end{array}$} & \multicolumn{3}{c|}{$\begin{array}{c}\text { Amount (isolate)/ } \\
\text { Percentage (\%) }\end{array}$} \\
\cline { 2 - 7 } & $\mathrm{S}$ & $\mathrm{I}$ & $\mathrm{R}$ & $\mathrm{S}$ & $\mathrm{I}$ & $\mathrm{R}$ \\
\hline Penicilin G & $1 / 33$ & 0 & $2 / 67$ & $\begin{array}{c}10 / 45 . \\
5\end{array}$ & 0 & $12 / 54.5$ \\
\hline Ampicillin & $2 / 67$ & 0 & $1 / 33$ & $\begin{array}{c}10 / 45 . \\
5\end{array}$ & $1 / 4.5$ & $11 / 50$ \\
\hline Tetracycline & $3 / 100$ & 0 & 0 & $20 / 91$ & 0 & $2 / 9$ \\
\hline Doxycycline & $3 / 100$ & 0 & 0 & $22 / 100$ & 0 & 0 \\
\hline Erythromycin & $3 / 100$ & 0 & 0 & $\begin{array}{c}14 / 63 . \\
7\end{array}$ & $1 / 4.5$ & $7 / 31.8$ \\
\hline Ciprofloxacin & $3 / 100$ & 0 & 0 & $20 / 91$ & $1 / 4.5$ & $1 / 4.5$ \\
\hline Gentamicin & $3 / 100$ & 0 & 0 & $22 / 100$ & 0 & 0 \\
\hline Streptomycin & $2 / 67$ & 0 & $1 / 33$ & $16 / 73$ & $2 / 9$ & $4 / 18$ \\
\hline
\end{tabular}

S: Sensitive, I: Intermediate, R: Resistance

\section{DISCUSSION}

\section{A. Occurrences and Agents of Subclinical Mastitis Causes}

Further tests of quartered milk samples were carried out to determine the bacteria Staphylococcus sp. as a cause of subclinical mastitis infection. Identification was first carried out in blood agar then continued observing the characteristics of bacterial colonies (blood hemolysis). Furthermore Staphylococcus sp. isolated and identified based on macroscopic and microscopic morphology, as well as biochemical tests. Staphylococcus sp. has Gram-positive characteristics, wine-like colonies, nonspores, positive catalase, and negative oxidase. Tests on MSA and rabbit plasma were done to distinguish between positive Staphylococcus coagulase (CPS) and negative coagulase (CNS). Staphylococcus aureus is shown by the growth of yellow colonies and the media to change from red to yellow on MSA media. Positive coagulase in S. aureus is shown by macroscopic clot formation in rabbit plasma.

Staphylococcus sp. is one of the bacteria that is found as a cause of subclinical mastitis infection. Staphylococcus aureus, Streptococcus agalactiae, and Escherichia coli are major contagious pathogens, while CNS is a minor environmental pathogens that causes subclinical mastitis [17]. The number of CNS isolates successfully isolated in this study was more than $S$. aureus isolates. This was in accordance as in [18] who reported that $26.71 \%$ of milk samples were contaminated by Staphylococcus sp., Respectively CPS and CNS were isolated as much as $11.64 \%$ and $15.05 \%$ of cow's milk samples were infected with subclinical mastitis. Reference [19] and [20] stated that there was a change in tendency from $S$. aureus to CNS as a bacterium that causes infectious mastitis. This situation could be caused by hygiene and sanitation during milking [21].

\section{B. Antibiotic Resistance}

The bacterial properties determined from the inhibition zone are sensitive (S), intermediate (I) and resistant (R) [22]. The results of this study indicate that $S$. aureus were still sensitive to tetracycline, doxycycline, erythromycin, ciprofloxacin, and gentamicin. Some S. aureus were quite sensitive to ampicillin (67\%) and streptomycin (67\%), whereas penicillin $\mathrm{G}$ was less sensitive $(33 \%)$. S. aureus isolates were resistant to ampicillin (33\%), streptomycin (33\%), and penicillin $\mathrm{G}(67 \%)$. The results of the CNS isolate resistance test showed that CNS had diverse sensitivity to the antibiotics tested. Test results show CNS were still sensitive to doxycycline and gentamicin. Some CNS were quite sensitive to tetracycline and ciprofloxacin in the same amount $(90.91 \%)$. A fairly sensitive trait was also shown by CNS isolates in streptomycin (72.73\%) and erythromycin $(63.64 \%)$. A considerable amount of CNS isolates to antibiotics were shown in the $\beta$-lactam group, namely penicillin $\mathrm{G}(54.55 \%)$ and ampicillin $(50 \%)$.

Antibiotic resistance test results showed that $S$. aureus and CNS isolates from fresh milk from cows infected with subclinical mastitis were still sensitive to doxycycline and gentamicin. In contrast to CNS, S. aureus isolates showed that the bacteria were also still sensitive to tetracycline, erythromycin, and ciprofloxacin. Reference [23] reported that Staphylococcus sp. in cases of subclinical mastitis resistant to ampicillin, but still sensitive to erythromycin $(20.34 \%)$, tetracycline $(20.34 \%)$, chloramphenicol $(16.95 \%)$, and gentamicin (56\%). Reference [24] in their research found that $S$. aureus isolates were still sensitive to gentamicin. 
Antibiotic resistance tests showed that CNS tends to be more resistant to 6 of 8 types of antibiotics. This was different from $S$. aureus which tends to only be resistant to 3 of 8 types of antibiotics. S. aureus and CNS tend to be resistant to the same three antibiotics, with the highest percentage levels of resistance to these antibiotics being the highest being penicillin, ampicillin, and streptomycin. The results of comparison of the percentage of $S$. aureus and CNS resistance levels to antibiotics can be seen in Figure 3.

Staphylococcus aureus and Staphylococcus coagulase negative were found to be resistant to penicillin $G$ and ampicillin. Reference [25] reported that $\mathrm{S}$. aureus and CNS bacterial isolates from mastitis cases in dairy cows were resistant to penicillin $\mathrm{G}$ and ampicillin. This is supported as in [26] that S. aureus and CNS are resistant to penicillin G $(29.9 \%)$ and ampicillin (1.0\%). B-lactam antibiotics such as penicillin and ampicline are effective against Staphylococcus and are often used as the drug of choice for fighting infections. Gram positive bacteria have a thick outer cell wall consisting of peptidoglycan which is useful for protecting bacteria from the host defense system [27]. Bacterial resistance to $\beta$-lactam antibiotics can be caused by bacteria containing penicillin-binding protein (PBP) which have a low affinity for $\beta$-lactam antibiotics. The formation of these proteins is triggered through continuous bacterial contact with antibiotics [28].

S. aureus and CNS resistance to streptomycin antibiotics was found in this study. Based on reference [29] the contribution of bacterial resistance to streptomycin is due to its excessive use to treat subclinical mastitis. The mechanism of bacterial resistance to streptomycin in the form of mutations and random mutation selection. These mutations can change the normal binding site of streptomycin in bacterial ribosomes [30].

CNS resistance tends to be quite low in the antibiotics erythomycin (31.82\%), tetracycline $(9.09 \%)$, and ciprofloxacin $(4.55 \%)$. Erythromycin is a macrolide class of antibiotics that are often used in intramamary treatment. According to [31] resistance to erythromycin can be caused by changes in the target ribosome mediated by methyl-ase from the eryhtomicin resistance methylase (erm) (B) gene, the drug-efflux mechanism mediated by the macrolides efflux genes (mef) gene (A). ), and mutations in 23S rRNA or L4 and 22 ribosomal proteins.

Tetracycline is a broad-spectrum antibiotic that has quite a good effectiveness against Staphylococcus. Tetracycline resistance is associated with cellular genetic elements that carry tetracycline resistance genes, mutations in the ribosome binding site, and chromosomal mutations that lead to increased expression of intrinsic resistance mechanisms. The resistance mechanism in tetracycline is efflux pump, ribosomal protection, and enzymatic inactivation of tetracycline [32].

The mechanism of bacterial resistance to the ciprofloxacin antibiotic is efflux pump and target modification. Efflux pump mechanism occurs because of the faster energy that will release antibiotics, so that antibiotics cannot enter the bacterial cell. Gene mutations make it possible for bacteria to be able to modify the target that is attached to the antibiotic so that the antibiotic becomes dysfunctional [30].
The results of resistance studies also found that $3 \mathrm{CNS}$ isolates were multidrug-resistant (MDR). Multidrugresistant is a condition of bacterial isolates that are resistant to 3 or more classes of antibiotics [33]. CNS experienced the highest multidrug-resistant in 3 classes of antibiotics, including $\beta$-lactam, tetracycline, and aminoglycosides. The multidrug-resistant is a marker that there are many types of antibiotics used on farms. This causes difficulties in the treatment of diseases that have an impact on economic losses due to a decline in health, production, and quality of milk yields and have an impact on public health [34].

The effectiveness of antibiotics against S. aureus and CNS bacteria varies. The cause of such diversity is due to bacteria having undergone changes in protein-binding site, changes in bacterial wall components, and cell membranes and enzymes that can fight certain antibiotics. Antibiotic resistance is triggered by the continuous use of antibiotics with inappropriate dosages and procedures. This needs to be overcome so that the control and treatment of subclinical mastitis can take place optimally.

\section{REFERENCES}

[1] A. M. Legowo, Sifat Kimiawi, Fisik, dan Mikrobiologi Susu. Semarang: Universitas Diponegoro, 2002.

[2] Kementerian Pertanian, Outlook Komoditas Pertanian Subsektor Peternakan: Susu, Jakarta: Pusat Data dan Sistem Informasi Pertanian, 2016.

[3] Subronto, Ilmu Penyakit Ternak I. Yogyakarta: Gadjah Mada Univ Press, 2003.

[4] I. S. Nurhayati and E. Martindah, "Pengendalian mastitis subklinis melalui pemberian antibiotik saat periode kering pada sapi perah," Wartazoa, in press.

[5] M. Poeloengan, "Pengaruh minyak atsiri serai (Andropogon citratus DC) terhadap bakteri yang diisolasi dari sapi mastitis subklinis," Berita Biol, in press.

[6] N. M. Herlina, F. Afiati, A. D. Cahyo, P. D. Herduyani, Qurotunnada, and B. Tappa, "Isolasi dan identifikasi Staphylococcus aureus dari susu mastitis subklinis di Tasikmalaya, Jawa Barat," Pros Sem Nas Masy Biodiv Indon, in press.

[7] B. Topuzoğlu, A. Baştan, and S. Salar, "The effect of long term antibiotic treatment on bacteriological cure and somatic cell count at subclinical mastitis due to Staphylococcus aureus in lactating dairy cows," Vet J Ankara Univ, in press.

[8] M. Oliveira, R. Bexiga, S. F. Nunes, C. Carneiro, L. M. Cvaco, F. Bernardo, C. L. Vilela, "Biofil-forming ability profiling of Staphylococcus aureus and Staphylococcus epidermidis mastitis isolates," Vet Microbiol, in press.

[9] M. Bochniarz, W. Wawron, M. Szczubial, "Coagulase-negative Staphylococci (CNS) as an aetiological factor of mastitis in cows," Polish J Vet Sci, in press.

[10] D. Chandrasekaran, P. Venkatesan, K. G. Tirumurugaan, A. P. Nambi, P. S. Thirunavukkarasu, K. Kumanan, S. Vairamuthu, S Ramesh, "Pattern of antibioitic resistant mastitis in dairy cows," Vet World, in press.

[11] H. W. Barkema, Y. H. Schukken, R. N. Zadoks, "Invited review: The role of cow, pathogen, and treatment regimen in the therapeutic success of bovine Staphylococcus aureus mastitis," J Dairy Sci, in press.

[12] World Health Organization, Global action plan on antimicrobial resistance [Internet]. [diunduh pada 2019 Jan 31] tersedia pada: http://www.who.int/antimicrobial-resistance/global-action-plan/en/

[13] H. Pisestyani, M. Sudarwanto, R. Wulansari, A. Atabany, "Data dasar perancangan alat celup puting sesuai dengan bentuk puting sapi perah di Jawa Barat," Acta Vet Indones, in press.

[14] M. B. Sudarwanto, E. Sudarnika, "Hubungan antara pH susu dengan jumlah sel somatik sebagai parameter mastitis subklinilk," Med Pet, in press. 
[15] M. B. Sudarwanto MB, "Pereaksi IPB-1 sebagai pereaksi alternatif untuk mendeteksi mastitis subklinis," Med Vet, in press.

[16] S. Virdis, C. Scarano, F. Cossu, V. Spanu, C. Spanu, Santis, "Antibiotic resistance in Staphylococcus aureus and Coagulase Negative Staphylococci isolated from goats with subclinical mastitis," Vet Med Int, in press.

[17] A. Abdel-Rady, M. Sayed, "Epidemiological studies on subclinical mastitis in dairy cows in Assitu Governorate," Vet World, in press.

[18] M. A. Islam, A. K. M. A. Rahman, S. A. Rony, M. S. Islam ," Prevalence and risk factors of mastitis in lactating dairy cows at Baghabari milk shed area of Sirajganj," BJVM, in press.

[19] N. Sharma, G. J. Rho, Y. H. Hong, T. Y. Kang, H. K. Lee, T. Y. Hur, D.K. Jeong, "Bovine mastitis: an Asian perspective," AJAVA, in press.

[20] P. Mahlangu, N. Maina, J. Kagira, "Prevalence, risk factors and antibiogram of bacteria isolated from milk of goats with subclinical mastitis in Thika East Subcounty, Kenya," J Vet Med, in press.

[21] S. Björk, R. Båge, B. M. Kanyima, S. Andre, M. G. NassunaMusoke, D. O. Owiny, Y. Persson, "Characterization of coagulase negative Staphylococci from cases of subclinical mastitis in dairy cattle in Kampala, Uganda," Irish Vet J, in press.

[22] Clinical and Laboratory Standards Institute, Performance Standards for Antimicrobial Susceptibility Testing: Twenty-Second Informational Supplement, West Valley: Clinical and Laboratory Standards Institute, 2017.

[23] N. Sharma, S. K. Maiti, K. K. Sharma, "Prevalence, etiology, and antibiogram of microorganisms associated with sub-clinical mastitis in buffaloes in Durg, Chhattisgarh State (India)," Int J Dairy Sci, in press.

[24] D. P. Kateete, U. Kabugo, H. Baluku, L. Nyakarahuka, S. Kyobe, M. Okee, C. F. Najjuka, M. L. Joloba ML, "Prevalence and antimicrobial susceptibility bacteria from milkmen and cows with clinical mastitis in and around Kampala, Uganda," PLOS ONE, in press.
[25] H. Turutoglu, S. Ercelik, D. Ozturk, "Antibiotic resistance of Staphylococcus aureus and coagulase-negatif Staphylococci isolated from bovine mastitis," Bull Vet Inst Pulawy, in press.

[26] F. Kunz, S. Corti, N. Giezendanner, R. Stephan, M. M. Wittenbrink, C. Zweifel, "Antibiotikaresistanz von Staphylococcus aureus und Koagulase-negativen Staphylokokken isoliert aus mastitismilchproben von Schafen und Ziegen," Schweiz Arch Tierheilkd, in press.

[27] M. H. Effendi, "Pembuktian horizontal transfer of resistance genes melalui uji sensitivitas antibiotika pada bakteri genus Staphylococcus dari kasus bovine mastitis," Berk Penel Hayati, in press.

[28] K. Becker, C. Heilmann, G. Peters, "Coagulase-negative Staphylococci," Clin Microbiol Rev, in press.

[29] P. Mahlangu, N. Maina, J. Kagira, "Prevalence, risk factors and antibiogram of bacteria isolated from milk of goats with subclinical mastitis in Thika East Subcounty, Kenya," J Vet Med, in press.

[30] T. J. Foster, "Antibiotik resistance in Staphylococcus aureus current status and future prospects," FEMS Microbiol Rev, in press.

[31] S. Kanoh, B. K. Rubin, "Mechanism of action and clinical application of macrolides as imunomodulatory medications," Clin Microbiol Rev, in press.

[32] T. H. Grossman TH, "Tetracycline antibiotics and resistance," Cold Spring Harb Perspect Med, in press.

[33] A. P. Magiorakos, A. Srinivasan, R. B. Carey, Y. Carmeli, M. E Falagas, C. G. Giske, S. Harbarth, G. Kahlmeter, B. OlssonLiljequist, D. L. Paterson, L. B. Rice, J. Stelling, J. Struelens, A. Vatopoulos, J. T. Weber, D. L. Monnet, "Multidrug-resistant, extensively drug-resistant and pandrug resistant bacteria: an international expert proposal for interim standard definitions for acquired resistance," Clin Microbiol Infect, in press.

[34] L. Sharma L, A. K. Verma, A. Kumar, A. Rahat, Neha, R. Nigam, "Incidence and pattern of antibiotic resistance of Staphylococcus aureus isolated from clinical and subclinical mastitis in cattle and buffaloes," AJAVA, in press. 